\title{
ANALISIS KEPEMILIKAN SERTIFIKAT HALAL TERHADAP TINGKAT PENDAPATAN USAHA PELAKU INDUSTRI KECIL DAN MENENGAH
}

\author{
Syaeful Bakhri \\ Fakultas Syariah dan Ekonomi Islam \\ IAIN Syekh Nurjati Cirebon, Indonesia \\ Email: sultanOlaulia@yahoo.com
}

\begin{abstract}
Small and Medium Industries (SMIs), which have halal certificates are still very limited in Cirebon Regency. Based on data from the Department of Industry and Trade of Cirebon Regency, only 3\% or around 429 of the 14,282 SMIs have halal certificates. The opportunity of SMIs in growing regional economy is undeniable, the ownership of halal certificates for SMEs is an opportunity, besides getting public recognition it also has the opportunity to increase revenue. The purpose of this study is to find out and analyze the related income before and after having a halal certificate and try to prove the relationship of ownership of halal certificates to the level of income of SMIs. The research method used was descriptive quantitative through Chi-Square Test and T-test involving 43 respondents. The results of the study through the ChiSquare Test showed a p-value of $0.021<(0.05)$, which explains there is a direct relationship between halal certificate ownership and the business income of SMEs. On the same occasion, ownership of the certificate will have an impact of about 2.4 times increasing the income of SMEs who have been halal-certified, with an Odds Ratio (OR) of 2,357. The positive effects of certificate ownership can increase income while proving that halal certificates have a significant relationship in influencing the income of SMEs.
\end{abstract}

Keywords: Halal Certificate, Income, and SMIs.

\begin{abstract}
Abstrak
Industri Kecil dan Menengah (IKM) yang memiliki sertifikat halal masih sangat terbatas di Kabupaten Cirebon. Berdasarkan data Dinas Perindustrian dan Perdagangan Kabupaten Cirebon hanya 3\% atau sekitar 429 dari 14.282 IKM yang memiliki sertifikat halal. Peluang IKM dalam menumbuhkan ekonomi daerah tidak terbantahkan, kepemilikan sertifikat halal bagi pelaku IKM merupakan sebuah opportunity, disamping mendapatkan pengakuan publik juga berpeluang meningkatkan Pendapatan. Tujuan penelitian ini adalah mengetahui dan menganalisis terkait pendapatan sebelum dan sesudah memiliki sertifikat halal dan mencoba membuktikan hubungan kepemilikan sertifikat halal terhadap tingkat pendapatan pelaku IKM. Metode penelitian yang digunakan adalah deskriptif kuatitatif melalui Uji Chi-Square dan Uji t dengan melibatkan 43 responden. Hasil penelitian melalui Uji Chi-Square menunjukkan nilai p-value 0,021 < (0,05) yang menjelaskan ada hubungan secara langsung antara kepemilikan sertifikat halal dengan pendapatan usaha pelaku IKM. Pada kesempatan yang sama kepemilikan sertifikat akan berdampak sekitar 2,4 kali meningkatkan pendapatan pelaku usaha IKM yang telah bersertifikat halal, dengan nilai Odd Ratio (OR) sebesar 2,357. Dampak positif kepemilikan sertifikat dapat meningkatkan pendapatan sekaligus membuktikan bahwa sertifikat halal memiliki hubungan yang signifikan dalam mempengaruhi tingkat pendapatan pelaku IKM.
\end{abstract}

Kata kunci: Sertifikat Halal, Pendapatan Usaha, dan IKM. 


\section{PENDAHULUAN}

Kabupaten Cirebon terletak pada wilayah strategis sebagai penghubung menuju pintu keluar masuk (gate) barang dan manusia seperti jalan arteri, jalan bebas hambatan, bandar udara, dan pelabuhan mendudukan wilayah Kabupaten Cirebon pada posisi yang paling strategis dibanding wilayah lain yang berbatasan langsung seperti Kota Cirebon, Kabupaten Majalengka, Kabupaten Indramayu, dan Kabupaten Kuningan. Dengan dimilikinya berbagai potensi sumber daya alam yang dimiliki, struktur ekonomi Kabupaten Cirebon terbentuk dengan dominasi sektor industri yang berbasis sumber daya alam. Wilayah Kabupaten Cirebon yang terdiri dari wilayah perkebunan, dataran pesawahan, hingga wilayah pesisir, menjadikan potensi ekonomi yang muncul menjadi semakin beragam. Didukung dengan posisi yang strategis, aksesibilitas yang mudah, serta sarana dan prasarana pendukung yang cukup memadai membuat Kabupaten Cirebon menjadi pilihan alternatif bagi para wisatawan, para investor industri kecil, sedang bahkan besar untuk mengembangkan usahanya. Oleh karenanya, maka tidak heran jika perekonomian Kabupaten Cirebon kini tumbuh dan berkembang dengan cukup pesat, hal ini ditandai pula dengan perkembangan industri yang kian mengalami peningkatan.

Perkembangan jumlah industri di Kabupaten Cirebon dapat dilihat dari data jumlah Industri Kecil dan Menengah (IKM) per tahun 2017 mencapai 14.282 unit usaha, pada akhir tahun 2018 unit usaha Industri Kecil dan Menengah di Kabupaten Cirebon meningkat hingga 14.526 unit usaha atau mengalami peningkatan sebesar $1,68 \%$ dari tahun sebelumnya (Disperdagin, 2019). Namun realitanya adalah perkembangan jumlah IKM tersebut ternyata belum mampu mendorong peningkatan IKM halal di Kabupaten Cirebon. Sebagaimana menurut Rodiya S.T M.M, Kasi Fasilitasi dan Standarisasi Industri Disperindagin Kabupaten Cirebon, menyebutkan bahwa hanya terdapat 429 IKM atau sekitar 3\% dari jumlah IKM di Kabupaten Cirebon yang sudah bersertifikat halal.

Hal ini tentu menjadi sebuah persoalan sekaligus tantangan yang paling nyata bagi Kabupaten Cirebon saat ini. Kewajiban sertifikasi halal telah dijelaskan dalam amanat Undang-undang Jaminan Pangan Halal (UU JPH) No. 33 Tahun 2014 Pasal 4 yang menyebutkan bahwa produk yang masuk, beredar dan diperdagangkan di Indonesia berkewajiban memiliki sertifikat halal. Kepemilikan standar halal yang universal juga penting bagi peningkatan kepercayaan pelanggan. (Destiana \& Astuti, 2019)

Oleh sebab itu, berupaya untuk meningkatkan jumlah produk industri yang bersertifikat halal merupakan hal mutlak sebagai pemenuh kebutuhan masyarakat Kabupaten Cirebon yang mayoritas masyarakatnya merupakan masyarakat muslim. Kepemilikan sertifikat halal bagi para pelaku IKM juga merupakan sebuah opportunity, disamping mendapatkan pengakuan publik juga berpeluang mendapatkan keuntungan sangatlah besar.

Sebagaimana paparan latar belakang diatas, maka penulis merasa perlu untuk melakukan kajian terkait penggalian potensi dan tantangan pengembangan Industri Kecil dan Menengah Halal di Kabupaten Cirebon terutama menyangkut pendapatan sebelum dan sesudah memiliki sertifikat halal.

\section{LITERATURE REVIEW}

Kajian terdahulu yang memiliki relevansi terkait prospek dan tantangan pengembangan IKM Halal di Kabupaten Cirebon adalah, antara lain; Pertama, (Khalimy, 2018) tentang Pelaksanaan Sertifikasi Halal Supplier IKM di Pasar Kue Kecamatan Plered Kabupaten Cirebon. Hasil penelitiannya menyatakan bahwa pelaksanaan sertifikasi masih membutuhkan dorongan dari berbagai pihak untuk memfasilitasi dan mensosialisasikan pentingnya sertifikasi halal. Hal tersebut dapat dimulai dari Pemerintah Daerah 
ataupun Perguruan Tinggi Islam agar konsen terhadap IKM dan sertifikasi halal.

Kedua, (Ridwan, Hartutiningsih, \& Hatuwe, 2014) yang membahas tentang Pembinaan IKM. Kegiatan pembinaan IKM pada Dinas Perindagkop dan UMKM Kota Bontang sangat bermanfaat terhadap pengembangan usaha pelaku IKM. Adapun faktor-faktor yang menjadi penghambat pembinaan IKM diantaranya berasal dari kurangnya kuantitas dan kualitas Pembina yang mendukung pelaksanaan kegiatan pembinaan, terbatasnya kemampuan Pembina serta anggaran yang kurang menunjang pelaksanaan kegiatan pembinaan. Faktor lainnya yaitu dari para pelaku IKM yang terkesan bersikap dan berfikir konsumtif serta kurangna perencanaan secara matang dalam pelaksanaan kegiatan pembinaan.

Ketiga, (Pujiono, Setyowati, \& Idris, 2018) yang membahas mengenai Strategi Pengembangan UMKM Halal di Jawa Tengah dalam Menghadapi Persaingan Global. Hasil analisis SWOT dalam penelitiannya menunjukkan strategi utama UMKM dalam menghadapi persaingan global adalah dengan cara meningkatkan sertifikasi halal, meningkatkan kualifikasi SDM, penggunaan teknologi modern dengan tepat, memperkuat hilirisasi industri, meningkatkan branding dan pemasaran dan memperkuat kajian fikih untuk menghasilkan produk halal serta meningkatkan peran dari berbagai lembaga ataupun institusi terkait inovasi, pendidikan dan literasi produk halal.

$$
\text { Keempat, }
$$$$
\text { (Heryanto }
$$

\& Jumiatiningrum, 2017) tentang Koordinasi Bidang Industri Dinas Perindustrian dan Perdagangan Kabupaten Cirebon Dalam Pembinaan Industri Kecil Menengah (IKM) Makanan Olahan di Kabupaten Cirebon. Diketahui bahwa IKM di Kabupaten Cirebon berada pada kondisi yang baik, namun sebagai pengembangan IKM di Kabupaten Cirebon, Disperindag perlu berperan aktif melakukan pergerakan yang dapat meningkatkan kapasitas IKM secara langsung seperti melakukan penyuluhan, pelatihan, bimbingan dan pembinaan controlling dengan di dukung oleh penambahan personel di bidang lapangan, dan juga pengadaan fasilitasi HKI dan pelatihan pengemasan produk.

\section{METODE PENELITIAN}

Dalam penelitian ini penulis menggunakan pendekatan kuantitatif. Pendekatan Kuantitatif bertujuan untuk mengembangkan model matematis, teori maupun hipotesis terkait dengan fenomena penelitian (Suryani \& Hendriyadi, 2015). Analisis data dapat berupa numerik/angka yang dapat mempresentasikan suatu adanya dan/atau besarnya suatu pengaruh antar variabel penelitian. Populasi ditentukan berdasarkan jumlah IKM yang sudah memiliki sertifikasi halal sebanyak 426 (Empat ratus dua puluh enam). Sampel diambil dari $10 \%$ dari jumlah populasi atau sebanyak 43 IKM yang telah bersertifikasi halal. Kuesioner dibuat dengan memberikan skor penilaian dengan menggunakan teknik skala Likert. Dalam penelitian ini, teknik pengumpulan data dan informasi yang digunakan adalah melalui observasi, wawancara, studi dokumentasi, Focus Group Discussion (FGD), dan studi kepustakaan.

Adapun metode analisis data yang digunakan pada analisis kuantitatif adalah dengan analisis univariat dan bivariate. Analisis univariat digunakan bertujuan untuk mengetahui gambaran distribusi frekuensi dari masing-masing variabel yang diteliti yang ditampilkan berupa ukuran statistik, grafik dan tabel.

Gambaran distribusi frekuensi tersebut kemudian dapat menguji pengaruh, komparasi, korelasi, dan lain-lain pada suatu variabel tertentu. Alat uji analisis statistik ini juga dapat menentukan hasil uji hipotesis terkait kualitas sebuah perlakuan seperti baik/ kurang baik, berhasil/ gagal, normal/ tidak normal ataupun rata-rata pada sebaran data.

Sementara itu, penggunaan analisis bivariate bertujuan untuk mengetahui hubungan antara variabel dengan uji 
keabsahan data menggunakan alat analisis SPSS dengan Pengujian statistik melalui uji chi-square. Notoatmodjo menjelaskan uji chi-square yaitu uji signifikan antara data yang diobservasi dengan data yang diharapkan dilakukan dengan batas kemaknaan $(\alpha<0,05)$ (Notoatmodjo, 2010). Untuk mengetahui besarnya hubungan antar variabel dapat menggunakan Prevalence Ratio (PR) atau Odd Ratio (OR) dengan 95\% CI (Confidence Interval).

\section{KONSEP DASAR}

\section{Konsep Industri Kecil dan Menengah Halal}

Industri kecil adalah suatu kegiatan ekonomi yang melakukan kegiatan mengubah barang dasar menjadi barang jadi/ setengah jadi dan atau barang yang kurang nilainya menjadi barang yang lebih tinggi nilainnya, yang memiliki tenaga kerja sebanyak 5-19 orang. Adapun industri menengah menurut Departemen Perindustrian dan Perdagangan dalam Pinti, yaitu suatu kegiatan ekonomi yang mengolah bahan mentah, bahan setengah jadi dan atau barang jadi menjadi barang lebih tinggi untuk penggunaannya yang memiliki investasi antara $\mathrm{Rp}$. 200.000.000,- sampai dengan 10.000.000.000,- tidak termasuk tanah dan bangunan tempat usaha (Pinti, 2013), dengan jumlah tenaga kerja sebanyak 20-99 orang (BPS Kabupaten Cirebon., 2020). Adapun pengertian Industri Kecil dan Menengah Halal merupakan suatu kegiatan usaha produksi, yang telah dinyatakan secara tertulis kehalalan produknya oleh MUI melalui serangkaian prosedur pemeriksaan yang terperinci oleh LPPOM MUI.

Kriteria Industri Kecil dan Menengah secara umum dapat dibedakan kedalam beberapa macam diantaranya menurut (Nayla, 2014), adalah berdasarkan:

\section{Pengelolaan bisnis.}

Manajemen yang digunakan dalam bisnis IKM sangatlah berbeda dengan waralaba. Manajemen ataupun pengelolaan bisnis pada bisnis IKM dipegang oleh pemilik IKM itu sendiri sementara pada waralaba, pengelolaan bisnis dipegang oleh pemilik franchise atau franchisor.

2. Modal usaha.

Modal yang digunakan dalam bisnis IKM umumnya berasal dari dana sendiri oleh sebab itu jumlah modal yang digunakan para pelaku IKM biasanya adalah terbatas.

3. Karyawan.

Karyawan pada bisnis IKM umumnya adalah penduduk lokal, alasannya adalah karena agar dapat mempekerjakan secara mandiri pada daerah tersebut, ataupun karena terbatasnya biaya untuk biaya upah karyawan yang berasal dari luar daerah.

4. Sifat usaha.

Dalam bisnis IKM, umumnya adalah bersifat usaha keluarga yang pada mulanya usaha ini dijalankan oleh anggota keluarga dan setelah berkembang, pemilik IKM akan mempekerjakan penduduk sekitar untuk ikut mengembangkan bisnisnya.

5. Teknologi.

Pada umumnya, penggunaan teknologi dalam bisnis IKM cenderung masih sederhana, yaitu berupa hanya penggunaan alat-alat tradisional sebagai pendukung proses produksi.

Peran Industri Kecil dan Menengah sendiri menurut Ni'mah adalah untuk membantu mengatasi adanya pengangguran; Membantu untuk mengentaskan kemiskinan; Membantu mengatasi ketimpangan dalam pembagian pendapatan; Membantu mencegah urbanisasi; Meningkatkan perkembangan lalu lintas perdagangan dan perekonomian pada umumnya; Membantu mengurangi tindak kriminal dan kejahatan; dan Mampu memberikan sumbangan terhadap Produk Domestik Bruto (PDB) suatu Negara (Ni'mah, 2018).

\section{Sertifikasi Halal}

Sertifikasi halal adalah serangkaian proses yang wajib dilakukan oleh pelaku usaha untuk membuktikan kehalalan atas uji 
pemeriksaan kandungan dan proses pembuatan produk pangan, obat-obatan maupun kosmetik yang dilakukan melalui lembaga penjamin halal dan dapat ditandai dengan dicantumkannya label halal pada produk.

Sertifikasi halal produk dan pangan di Indonesia ditangani oleh lembaga Majelis Ulama Indonesia (MUI) sesuai dengan ketetapan Undang-Undang Nomor 23 tahun 1992 tentang Kesehatan, Undang-Undang Undang-Undang Nomor 7 Tahun 1996 tentang Produk, Undang-Undang Nomor 8 Tahun 1999 tentang Perlindungan Konsumen, Peraturan Pemerintah Nomor 69 Tahun 1999 dan peraturan pelaksanaan lainnya tanggungjawab kehalalan produk makanan, minuman, obat-obatan, kosmetika dan produk lainnya, sehingga penjaminan kehalalaan tersebut merupakan suatu tanggung jawab bersama, tidak hanya individu dan tokoh agama semata namun juga menjadi tanggung jawab pemerintah.

Lebih lanjut dijelaskan dalam (Muslimah, Hamdani, \& Irfani, 2018) terkait ketetapan yang tercantum dalam pasal 10 ayat 1 Peraturan Pemerintah terkait dengan pelaksanaan sertifikasi halal, bahwa setiap individu yang memproduksi maupun yang memasarkan produk yang dikemas ke dalam wilayah Indonesia untuk dilakukannya sebuah perdagangan dan menyatakan bahwa produk yang diperdagangkan tersebut adalah halal bagi umat Islam, maka harus bertanggung jawab atas kebenaran pernyataan tersebut dan wajib mencantumkan keterangan atau tulisan halal pada label, secara spesifik Lembaga Pengkajian Pangan Obat-sobatan dan Kosmetik (LPPOM) Majelis Ulama Indonesia. Lembaga LPPOM MUI bertugas untuk menganalisis, mengkaji, membuat keputusan terkait produk-produk pada sektor pangan, obat-obatan, maupun kosmetika apakah aman untuk digunakan dan dikonsumsi baik dari sisi kesehatan dan utamanya dari sisi Agama Islam yaitu kehalalannya.
Sertifikasi halal memiliki peranan yang sangat penting bagi berbagai pihak terkait. Bagi produsen, sertifikasi halal dapat berperan sebagai pertanggung-jawaban produsen kepada konsumen muslim, dapat meningkatkan rasa kepuasan dan kepercayaan konsumen, dapat meningkatkan citra sekaligus daya saing perusahaan, dapat berfungsi sebagai startegi memperluas pemasaran yang kemudian dapat meningkatkan keuntungan, omset dan daya saing produsen/ perusahaan itu sendiri. Sementara bagi konsumen, sertifikasi halal dapat berfungsi sebagai jaminan konsumsi produk terhadap hal-hal yang tidak halal sehingga menimbulkan rasa tenang dan kepuasan atas kepastian dan perlindungan hukum (Khotimah, 2018).

\section{Pendapatan}

Sementara itu faktor-faktor yang dapat mempengaruhi pendapatan perindustrian makanan menurut (Butarbutar, 2016) adalah:

1. Modal, yaitu semua kekayaan yang dapat dipergunakan baik secara langsung maupun tak langsung selama dalam proses produksi untuk menambah output. Modal merupakan salah satu hal utama dalam setiap pelaksanaan usaha kecil maupun besar.

2. Tenaga kerja, adalah tidak hanya mencakup jumlah buruh yang terdapat dalam suatu perekonomian, akan tetapi tenaga kerja juga menyangkut keahlian dan keterampilan yang masyaraat miliki. Tenaga kerja jika dalam hal pendidikannya dapat dibedakan menjadi 3 golongan, yaitu a). tenga akerja kasar, atau tenaga kerja yang tidak memiliki tidak berpendidikan atau rendah pendidikannya, dan tidak memiliki keahlian di bidang pekerjaannya. b). Tenaga kerja terampil, adalah mereka yang memiliki pengalaman maupun keahlian dan pelatihan kerja seperti pelatihan montir untuk mobil, dan ahli reparasi TV dan AC. c). Tenaga kera terdidik, adalah 
tenaga kerja yang memiliki pendidikan yang cukup serta memiliki keahlian di suatu bidang pekerjaan seperti dokter, perawat dan ekonom.

3. Lama usaha, adalah lamanya pedagang melakukan usaha yang sedang dijalani sampai saat ini. lamanya seseorang dalam melakukan suatu usaha akan berpengaruh pada pengalaman pelaku usaha dan jumlah pendapatan usaha yang didapat. Lamanya usaha yang sudah ditekuni selama ini akan membantu melahirkan pengalaman dan pembelajaran baru terhadap pelaku usaha sehingga kegiatan produktivitasnya akan berjalan lebih efektif dan efisien.

Semakin lama seseorang menekuni susaha pada suatu bidang, maka akan semakin meningkatkan pengetahuan strategi pengembangan usaha sebeprti selera mapun perilaku konsumen.

\section{PEMBAHASAN DAN DISKUSI}

Berdasarkan kerangka awal penelitian, untuk responden pelaku IKM ditetapkan 43 responden yang telah bersertifikasi halal. Namun dalam perkembangannya, tidak semua responden yang memiliki sertifikat halal bersedia untuk diwawancara/mengisi kuesioner. Agar tetap sesuai kerangka awal, berkenaan dengan jumlah responden, peneliti menggati responden yang tidak bersedia dengan melakukan wawancara/pengisian kuesioner kepada pelaku IKM yang belum memiliki sertifikat halal namun memiliki keinginan untuk mengurus dan memiliki sertifikat halal. Hal tersebut, bermanfaat bagi peneliti untuk dapat menggali informasi dari dua sudut pandang yang berbeda baik itu pada saat sebelum maupun setelah memiliki sertifikat halal.

Pengumpulan informasi dan diskusi pengembangan IKM halal di Kabupaten Cirebon dilakukan melalui Focus Group Discussion (FGD). Berikut merupakan hasil penelitian dan pembahasan yang kami sajikan dalam bentuk tabel maupun diagram dengan tujuan memudahkan para pembaca dalam memahami hasil penelitian ini.

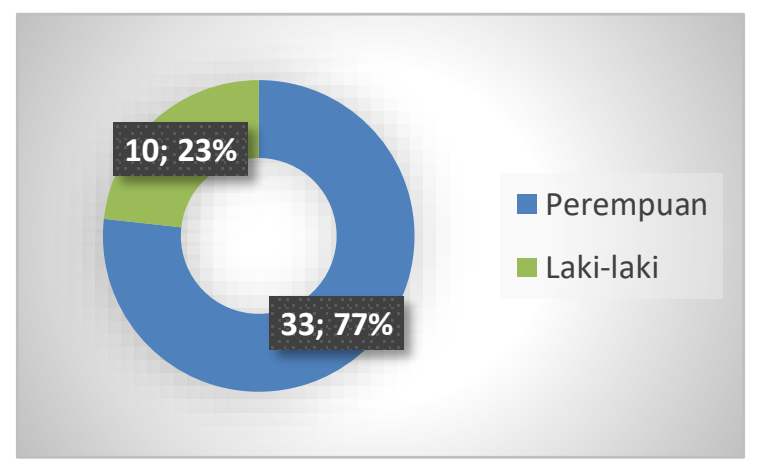

Sumber: Data Primer, 2019 (diolah)

\section{Gambar 1. Jenis Kelamin Responden}

Berdasarkan data pada gambar 1 dibawah menunjukkan bahwa dari 43 pelaku IKM yang menjadi responden, didominasi oleh perempuan sebanyak $33 \quad(76.7 \%)$ responden dan hanya terdapat $10(23.3 \%)$ responden saja yang berjenis kelamin lakilaki.

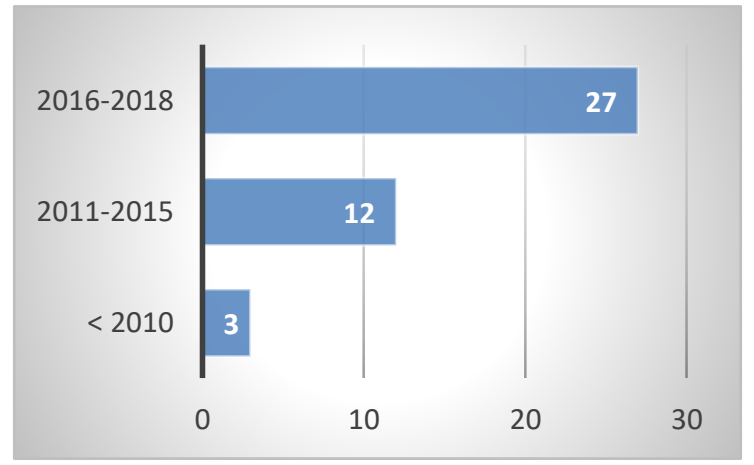

Sumber: Data Primer, 2019 (diolah)

\section{Gambar 2. Tahun berdiri IKM}

Berdasarkan gambar 2 dari 43 responden, pelaku IKM mayoritas didominasi oleh pelaku yang baru berdiri empat tahun terakhir, yakni dari tahun 20162018 sebanyak 27 (63\%) responden. Sementara itu, IKM yang berdiri dari tahun 2011-2015 terdapat 12 (28\%) responden dan IKM yang telah berdiri dari dan sebelum tahun 2010 hanya terdapat $3(7 \%)$ responden. 
Terkait dengan hal pengembangan IKM Halal di Kabupaten Cirebon terutama komitmen pemerintah dalam mewujudkan Cirebon sebagai Kabupaten Halal, permodalan tentunya merupakan hal utama dalam menjalankan suatu usaha, termasuk Industri Kecil dan Menengah. Modal yang digunakan pelaku usaha dapat bersumber dari modal sendiri, namun apabila modal tersebut tidak mencukupi biasanya pelaku usaha menambahkannya dengan modal yang didapat dari bantuan maupun pinjaman guna memenuhi kebutuhan usahanya.

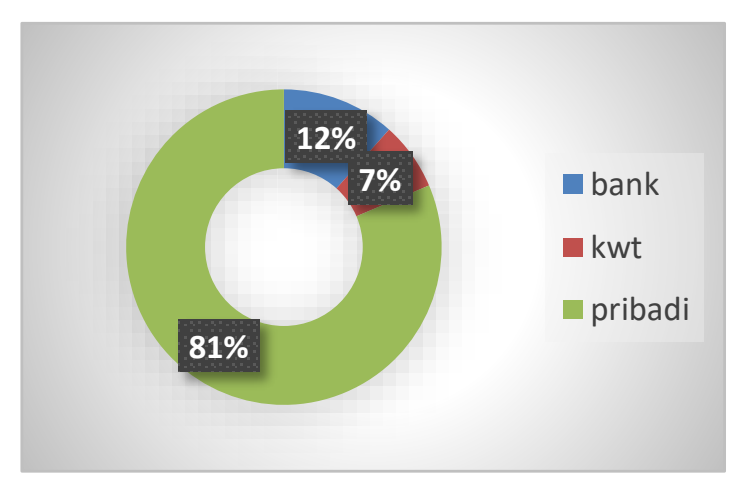

Sumber: Data Primer, 2019 (diolah)

Gambar 3. Sumber Modal

Berdasarkan data pelaku IKM yang mengisi kuesioner pada gambar 3, dibawah ini terlihat mayoritas diantara mereka menggunakan sumber modal usahanya adalah berasal dari tabungan pribadi atau mandiri, hal tersebut dibuktikan dengan didapatnya $35(81 \%)$ pelaku IKM yang menyatakan hal demikian. Pelaku IKM yang menyatakan sumber modalnya berasal dari pinjaman bank terdapat 5 (12\%) responden, dan pelaku IKM yang menyatakan sumber modalnya berasal dari bantuan KWT (Kelompok Wanita Tani) hanya terdapat 3 (7\%) responden.

Terkait hal sumber permodalan, sebagaimana yang tercantum dalam UndangUndang Republik Indonesia Nomor 20 Tahun 2008 pasal 22 Tentang Usaha Mikro, Kecil, dan Menengah yang membahas arah kebijakan pengembangan IKM terhadap sumber pembiayaan IKM yaitu bahwa Pemerintah Daerah perlu untuk menumbuhkan, mengembangkan, dan memperluas jaringan lembaga keuangan bukan bank berupa pembiayaan atau pinjaman. Hal tersebut dapat dilakukan melalui cara peningkatkan kemampuan dalam menyusun studi kelayakan usaha, peningkatan pengetahuan pelaku IKM tentang prosedur pengajuan pinjaman ataupun pembiayaan dan peningkatan pemahaman dan keterampilan teknis serta manajerial usaha.

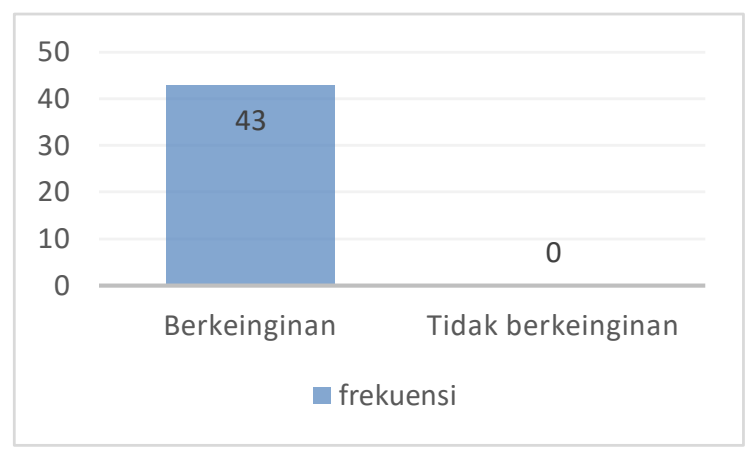

Sumber: Data Primer, 2019 (diolah)

Gambar 4. Keinginan Memiliki Sertifikat Halal

Keinginan dapat diartikan sebagai segala sesuatu yang sifatnya diluar dari kebutuhan terhadap barang maupun jasa yang ingin terpenuhi oleh setiap manusia. Adapun setelah ditanyakan lebih lanjut kepada responden yang belum memiliki sertifikat halal mengenai keinginan mereka terhadap kepemilikan sertifikat, mereka kompak menyuarakan ingin memiliki sertifikat halal. Hal tersebut dibuktikan pada gambar 4 yang menjelaskan 100\% diantara mereka menyatakan berkeinginan memiliki sertifikat halal. Dengan adanya rasa keinginan tersebut, pelaku usaha akan termotivasi untuk menggerakkan dirinya agar dapat memenuhi keinginannya memiliki sertifikat halal. Dalam hal ini jelaslah bahwa pelaku usaha IKM sepakat untuk mendukung pengembangan IKM halal di Kabupaten Cirebon. 


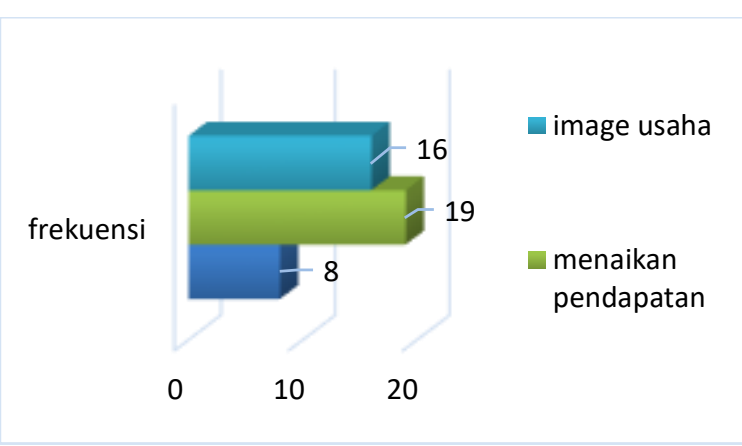

Sumber: Data Primer, 2019 (diolah)

Gambar 5. Faktor Keinginan

Motivasi yang digambarkan diatas, dapat disebabkan oleh beberapa hal. Diketahui berdasarkan gambar 5, bahwa diantara beberapa faktor yang mendorong lahirnya motivasi para pelaku IKM untuk berkeinginan mengurus sertifikat halal, mayoritas diantaranya adalah disebabkan oleh adanya harapan meningkatkan pendapatan usaha. Hal tersebut dibuktikan dari 43 pelaku IKM yang menjadi responden, $19(44.2 \%)$ responden menyatakan alasan untuk meningkatkan pendapatan usaha. Selain faktor tersebut, 16 (37.2\%) responden lainnya juga menyatakan faktor timbulnya keinginan untuk mengurus sertifikat halal adalah dikarenakan untuk meningkatkan citra atau image usaha. Sementara itu, 8 $(18.6 \%)$ responden sisanya menyatakan keinginan tersebut adalah sebagai bentuk penerapatan anjuran dari kebijakan pemerintah.

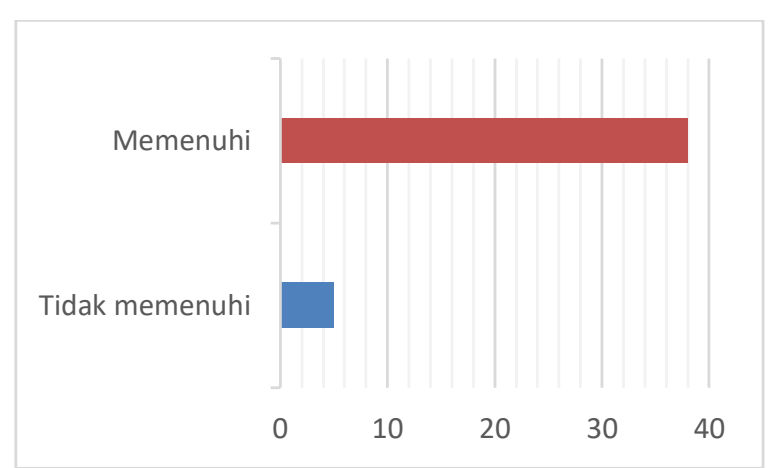

Sumber: Data Primer, 2019 (diolah)

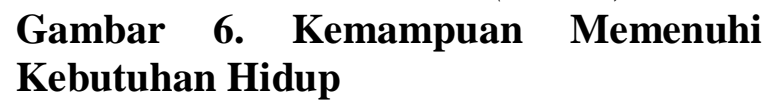

Berdasarkan gambar 6. mengenai kemampuan memenuhi kebutuhan, sebanyak $38(88.4 \%)$ responden total 43 pelaku IKM yang menjadi responden menyatakan telah mampu memenuhi kebutuhan hidup. Namun $5(11.6 \%)$ responden lainnya menyatakan tidak mampu memenuhi kebutuhan hidup. Kemampuan dalam memenuhi kebutuhan merupakan sebuah ukuran minimal dalam keberhasilan pelaku usaha menjalankan perdagangannya. Tujuan pelaku usaha untuk melakukan usahanya tentu terlebih dulu adalah untuk memenuhi kebutuhan hidup sehari-hari. Tujuan berikutnya dapat berupa pemenuhan kebutuhan modal untuk meningkatkan produksi dalam menjalankan usahanya.

Adapun sebagaimana temuan diatas yang mencerminkan adanya beberapa responden yang belum mampu memenuhi kebutuhan hidupnya, maka pemerintah dapat berupaya untuk meningkatkan motivasi dan inovasi para pelaku usaha, melakukan pembinaan dan pendampingan agar terus semangat menjalankan usahanya dan turut serta berperan mendukung peningkatan daya saing IKM Halal di Kabupaten Cirebon.

tidak kesulitan $\square$ ada kesulitan

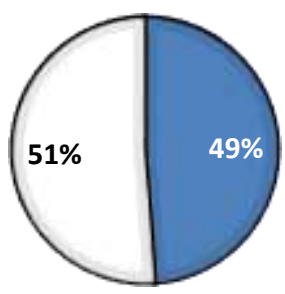

Sumber: Data Primer, 2019 (diolah)

\section{Gambar 7. Kesulitan Mendapatkan Bantuan Permodalan}

Fasilitasi permodalan adalah sesuatu hal yang sangat dibutuhkan oleh para pelaku IKM untuk menjalankan usahanya. Berdasarkan data pada gambar 7, diantara 43 responden pelaku IKM sebagian besar diantaranya masih kesulitan dalam mendapatkan bantuan permodalan, hal tersebut dibuktikan dengan adanya $22(51 \%)$ 
responden menyatakan adanya kesulitan, dan $21(49 \%)$ responden menyatakan tidak ada kesulitan.

Bantuan fasilitasi permodalan berfungsi untuk mendukung pengembangan kewirausahaan dan keunggulan kompetitif IKM Halal di Kabupaten Cirebon. Dikatakan demikian, karena modal memiliki sifat produktif yang mampu meningkatkan kapasitas produksi. Selain itu, modal juga bersifat prospektif, yakni berperan untuk mempertahankan kondisi produksi dalam waktu yang akan datang. Kemudahan mengakses permodalan akan berpengaruh pada kreatifitas pemasaran dan bahkan pada berjalannya suatu kegiatan IKM dalam jangka panjang.

Oleh sebab itu, temuan diatas hendaknya menjadi catatan keras bagi penggiat pengembangan IKM Halal di Kabupaten Cirebon, agar tentunya dapat meningkatkan kemudahan akses pelaku usaha untuk mendapatkan bantuan permodalan baik itu dari lembaga keuangan formal maupun lembaga keuangan informal.

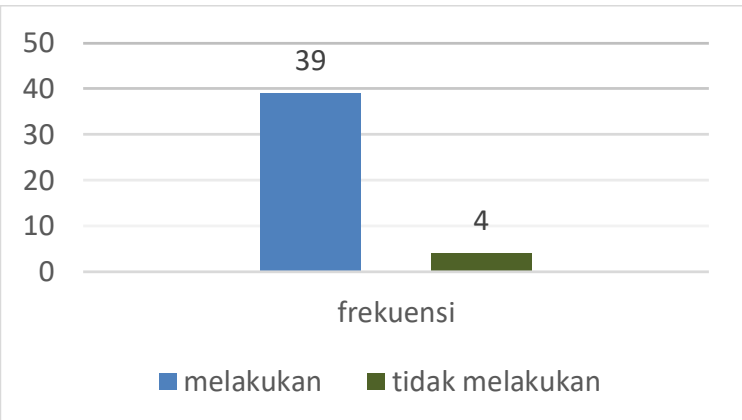

Sumber: Data Primer, 2019 (diolah)

Gambar 8. Kerjasama Pemasaran Produk

Pemasaran merupakan satu hal yang inti dalam dunia perdagangan. Dikatakan demikian, karena pemasaran adalah sistem yang berkaitan dengan seluruh kegiatan usaha yang dirancang untuk merencanakan, menentukan harga, mempromiskan, mendistribusikan kepada konsumen. Dalam penerapannya, biasanya para pelaku usaha melakukan kerjasama pemasaran guna menggabungkan sumberdaya maupun kompetensi yang dimiliki dua atau lebih pelaku usaha. Tujuannya adalah untuk menghasilkan suatu kemitraan, memperluas perspektif pemasaran sehingga sistem pemasaran dapat berjalan secara optimal.

Berdasarkan gambar 8 didapatkan temuan dari 43 responden pelaku IKM di Kabupaten Cirebon, 39 (90.7\%) responden diantaranya telah melakukan kerjasama untuk mengembangkan pemasaran produk responden, dan hanya terdapat $4(9.3 \%)$ responden saja yang belum melakukan kerjasama pengembangan pemasaran produknya.

\section{Analisis Univariat}

Tabel 1. Distribusi Frekuensi Data Numerik

\begin{tabular}{llll}
\hline $\begin{array}{l}\text { Variabel/ } \\
\text { Kategori }\end{array}$ & $\begin{array}{l}\text { Mean } \\
(\mathrm{Rp})\end{array}$ & $\begin{array}{l}\text { Median } \\
(\mathrm{Rp})\end{array}$ & Sd \\
\hline $\begin{array}{l}\text { Besar } \\
\text { modal }\end{array}$ & 21.979 .302 & 7.500 .000 & 3.923 \\
$\begin{array}{l}\text { Pendapatan } \\
\text { sebelum }\end{array}$ & 7.774 .137 & 3.750 .000 & 1.245 \\
$\begin{array}{l}\text { Pendapatan } \\
\text { setelah }\end{array}$ & 15.743 .103 & 8.000 .000 & 1.735 \\
\hline
\end{tabular}

Sumber: Data Primer, 2019 (diolah)

Analisis univariat ini bertujuan untuk menjelaskan ataupun mendeskripsikan kontribusi frekuensi dari masing-masing variable yang diteliti seperti pendapatan para Pelaku usaha IKM. Berdasarkan Tabel 1 diatas, diketahui rata-rata besar modal pelaku IKM saat ini adalah sebesar Rp. 21.979.302,. Adapun pendapatan pelaku IKM pada saat sebelum memiliki sertifikat sebesar Rp. 7.774.137,- dan rata-rata pendapatan setelah memiliki sertifikat sebesar Rp. 15.743.103,-.

\section{Analisis Bivariat (Uji Hubungan)}

Tabel 2. Uji Korelasi

\begin{tabular}{|c|c|c|c|c|c|c|}
\hline \multirow[t]{2}{*}{ Sertifikat } & \multicolumn{4}{|c|}{ Pendapatan Usaha } & \multirow{2}{*}{$\begin{array}{l}\text { P- } \\
\text { Value }\end{array}$} & \multirow[t]{2}{*}{ OR } \\
\hline & $\begin{array}{l}\text { Kurang } \\
\text { Baik }\end{array}$ & $\%$ & Baik & $\%$ & & \\
\hline Memiliki & 8 & 27.6 & 21 & 72.4 & & \\
\hline $\begin{array}{l}\text { Belum } \\
\text { Memiliki }\end{array}$ & 9 & 64.3 & 5 & 35.7 & 0.021 & 2.357 \\
\hline Total & 17 & 100 & 26 & 100 & & \\
\hline
\end{tabular}

Sumber: Data Primer, 2019 (diolah) 
Penggunaan alat analisis bivariat ini bertujuan untuk mengetahui hubungan antara dua variable, yakni antara kepemilikan sertifikat halal dengan pendapatan (income) usaha yang diperoleh oleh para pelaku IKM. Berdasarkan Tabel 2. diperoleh responden yang sudah memiliki sertifikat halal dan pendapatan usahanya kurang baik sebanyak $8(27.6 \%)$ responden, sedangkan responden yang sudah memiliki sertifikat halal dan pendapatan usahanya baik sebanyak 21 (72.4\%) responden. Sementara itu responden yang belum meiliki sertifikat halal dan pendapatan usahanya kurang baik terdapat 9 $(64.3 \%)$ responden, sedangkan responden yang belum memiliki sertifikat halal dan pendapatan usahanya baik terdapat $5(35.7 \%)$ responden.

Berdasarkan uji statistik melalui uji chi-square, diperoleh nilai p-value 0,021 > $(0,05)$ alpha dan menunjukkan adanya hubungan secara langsung antara kepemilikan sertifikat halal dengan pendapatan usaha pelaku IKM di Kabupaten Cirebon Tahun 2019. Hal tersebut menegaskan bahwa kepemilikan sertifikat halal merupakan faktor utama penentu pendapatan usaha pelaku IKM. Adapun dampak yang diberikan kepemilikan sertifikat halal terhadap peningkatan pendapatan usaha ditunjukkan dengan perolehan nilai Odd Ratio (OR) sebesar 2,357, yang berarti kepemilikan sertifikat halal mempunyai risiko sebesar 2,4 kali untuk dapat meningkatkan pendapatan dibandingkan dengan IKM yang belum memiliki sertifikat halal.

Hal ini sejalan dengan teori yang dikemukan Elmi dalam (Khotimah, 2018) yang menjelaskan bahwa sertifikasi halal dapat menjadi startegi memperluas pemasaran dan daya saing produk sekaligus meningkatkan keuntungan/ omset/ pendapatan produsen. Implikasinya, para pelaku IKM yang telah melakukan sertifikasi halal cenderung akan mencantumkan logo halal pada produknya, hal ini yang kemudian dapat mengendalikan niat dan keputusan konsumen untuk membeli produk tersebut.
Sebagaimana berdasarkan hasil beberapa kajian terdahulu seperti (Ma'rifat, Ismoyowati, \& Wikarta, 2015), (Handayani, 2019), (Listyoningrum \& Abari, 2012) serta penelitian (Balques, Noer, \& Nuzulfah, 2017) yang membuktikan adanya pengaruh positif kepemilikan sertifikat halal melalui logo halal yang dicantumkan pada produk terhadap sikap, nilai subjektif dan kontrol perilaku persepsi produk makanan halal dalam mengendalikan niat dan keputusan pembelian konsumen. Maka dapat dipahami, bahwa melalui sertifikasi halal para pelaku IKM dapat menggunakannya sebagai branding/alat marketing, meningkatkan citra dan daya saing produk untuk memperluas jaringan pemasaran dan pendapatan para pelaku IKM.

\section{Analisis Bivariat (Uji T)}

\begin{tabular}{llll}
\multicolumn{4}{c}{ Tabel 3. Analisis Bivariat } \\
\hline $\begin{array}{l}\text { Variabel/ } \\
\text { Kategori }\end{array}$ & Mean (Rp) & Sd & $\begin{array}{l}\text { P- } \\
\text { Value }\end{array}$ \\
\hline $\begin{array}{l}\text { Pendapatan } \\
\text { sebelum }\end{array}$ & 7.774 .137 & 1.245 & 0,000 \\
$\begin{array}{l}\text { Pendapatan } \\
\text { setelah }\end{array}$ & 15.743 .103 & 1.735 & \\
\hline
\end{tabular}

Sumber: Data Primer, 2019 (diolah)

Berdasarkan Tabel 3. hasil uji beda diperoleh rata-rata pendapatan sebelum memiliki sertifikat halal yaitu sebesar $\mathrm{Rp}$. 7.774.137,00 dan rata-rata pendapatan setelah memiliki sertifikat halal yaitu sebesar Rp. 15.743.103,00. Diperoleh nilai P-value 0,000 artinya ada perbedaan pendapatan usaha sebelum dan setelah memiliki sertifikat halal pada IKM di Kabupaten Cirebon pada Tahun 2019.

Merujuk pada data Tabel 2. tentang hasil uji hubungan/korelasi dan Tabel 3. tentang hasil uji $\mathrm{T}$ dapat diketahui bahwasanya dampak perbedaan pendapatan usaha yang terjadi pada pelaku IKM tentunya dibarengi dan disebabkan oleh faktor-faktor lain yang berpengaruh pada pendapatan usaha. Hal ini sejalan dengan hasil temuan empiris Butarbutar dan Malik, dkk terkait faktor-faktor yang dapat mempengaruhi hasil 
pendapatan usaha, diantaranya yaitu; (1) Faktor produksi berupa kecanggihan alat dan sarana produksi, ketersediaan bahan baku, tenaga kerja yang memadai; (2) Faktor SDM berupa keterampilan dan pengalaman para tenaga kerja; (3) Faktor finansial berupa kecukupan modal kerja; dan (4) Faktor pemasaran berupa kemudahan akses pemasaran produk dan perluasan kegiatan promosi (Butarbutar, 2016) yang dilakukan para pelaku IKM di Kabupaten Cirebon.

\section{KESIMPULAN}

Berdasarkan hasil penelitian dan pembahasan mengenai kepemilikan sertifikat halal pada pelaku IKM di Kabupaten Cirebon, hasil Uji Chi-Square menjelaskan bahwa ada hubungan secara langsung antara kepemilikan sertifikat halal dengan pendapatan usaha para pelaku IKM di Kabupaten Cirebon. Hal tersebut dibuktikan dengan diperolehnya nilai p-value $0,021<$ $(0,05)$ alpha, artinya kepemilikan sertifikat halal menjadi faktor pokok dalam peningkatan dan pendapatan usaha. Kepemilikan sertifikat akan berdampak sekira 2,4 kali untuk dapat meningkatkan pendapatan para pelaku usaha IKM yang telah bersertifikat halal. Dampak peningkatan pendapatan tersebut juga harus dibarengi dengan peningkatan mutu produksi, tenaga kerja yang memadai dan dukungan modal yang cukup. Hal ini dibuktikan dengan dengan nilai Odd Ratio (OR) sebesar 2,357.

Kemudahan akses dan fasilitasi kepemilikan sertifikasi halal merupakan kebijakan yang sangat dinanti oleh pelaku IKM di Kabupaten Cirebon. Menyangkut prosedur, biaya, jangka waktu, masa berlaku adalah beberapa hal yang menghambat pelaku IKM memiliki sertifikat halal.

\section{UCAPAN TERIMA KASIH}

Ucapan terima kasih kami haturkan kepada Kementerian Agama Republik Indonesia yang telah memberikan dana Penelitian melalui DIPA IAIN Syekh Nurjati Cirebon.

\section{DAFTAR PUSTAKA}

Balques, A., Noer, B. A., \& Nuzulfah, V. (2017). Analisis Sikap, Normal Subjektif, dan Niat Beli Produk Kosmetik Halal pada Konsumen Muslimah di Surabaya. Jurnal Teknik ITS, 6(2).

BPS Kabupaten Cirebon. (2020). Kabupaten Cirebon dalam Angka. Badan Pusat Statistik Kabupaten Cirebon. Retrieved from

https://cirebonkab.bps.go.id/publication /2020/04/27/58a42ed615363c51758f0d 0c/kabupaten-cirebon-dalam-angka2020.html

Butarbutar, G. R. (2016). Analisis Faktorfaktor yang Mempengaruhi Pendapatan Usaha Industri Makanan Khas di Kota Tebing Tinggi. JOMFekom, 4(1), 619633.

Destiana, R., \& Astuti, R. S. (2019). Pengembangan Pariwisata Halal di Indonesia. Collaborative Governance Dalam Pengembangan Pariwisata Di Indonesia, 01(01), 331-353.

Disperdagin. (2019). Perkembangan Industri di Kabupaten Cirebon Tahun 20172018. Disperdagin Kabupaten Cirebon.

Handayani, S. (2019). Peran Logo Dan Sertifikasi Halal Terhadap Niat Beli Konsumen Pada Restoran Cheese Chicken.

Heryanto, Y., \& Jumiatiningrum, S. N. (2017). Koordinasi Bidang Industri Dinas Perindustrian dan Perdagangan Kabupaten Cirebon Dalam Pembinaan Industri Kecil Menengah (IKM) Makanan Olahan di Kabupaten Cirebon. Syntax Literate : Jurnal Ilmiah Indonesia, Vol. 2, N, 166-175.

Khalimy, A. (2018). Pelaksanaan Sertifikasi Halal Supplier IKM di Pasar Kue Kecamatan Plered Kabupaten Cirebon Jawa Barat. Jurnal Et-Tijarie, 5(2).

Khotimah, U. K. (2018). Labelisasi Halal di Tengah Budaya Konsumtif. Jurnal Sosiologi Agama, Vol. 12, N, 283-296.

Listyoningrum, A., \& Abari. (2012). Analisis Minat Beli Konsumen Muslim terhadap 
Produk yang Tidak di Perpanjang Ekonomi Islam. Jakarta: Kencana.

Sertifikat Halalnya. Jurnal Ekonomu Dan Keungan Islam, 2(1), 40-51.

Ma'rifat, T. N., Ismoyowati, D., \& Wikarta, J. M. (2015). Analisis Perilaku KOnsumen dalam Pembelian Produk Olahan Ayam Bersertifikat Halal di Provinsi DI. Prosiding Seminar Agroindustri Dan Lokakarya Nasional FKPT-TPI Prodi TIP-UTM, 23(September).

Muslimah, A. N., Hamdani, H. I., \& Irfani, F. (2018). Pengaruh Brand Image Dan Sertifikasi Halal Terhadap Minat Beli Pelanggan (Studi Kasus Superkue Bogor). Jurnal Al Amwal, 1(1), 41-57.

Nayla, A. P. (2014). Komplet Akuntansi untuk UKM dan Waralaba. Yogyakarta: Laksana.

Ni'mah, A. luthfiana. (2018). Implmentasi Undang-undang Nomor 33 Tahun 2014 tentang Jaminan Produk Halal pada Produk Makanan Industri Kecil Menengah (IKM) di Tulungagung. IAIN Tulungagung.

Notoatmodjo, S. (2010). Metodologi Penelitian Kesehatan. Jakarta: Rineka Cipta.

Pinti, E. (2013). Pelaksanaan Penjualan Konsinyasi dalam Mengembangkan Usaha pada Industri Kecil dan Menengah (IKM) Pangan Kota Pekanbaru Ditinjau menurut Ekonomi Islam. UIN Al-Jamiah Sultan Syarif Kasim Riau.

Pujiono, A., Setyowati, R., \& Idris. (2018). Strategi Pengembangan UMKM Halal di Jawa Tengah dalam Menghadapi Persaingan Global. Indonesian Journal of Halal, 1(1).

Ridwan, M., Hartutiningsih, \& Hatuwe, M. (2014). Pembinaan Industri Kecil dan Menengah Pada Dinas Perindustrian, Perdagangan, Koperasi dan UMKM Kota Bontang. Jurnal Administrative Reform, 2(2).

Suryani, \& Hendriyadi. (2015). Metode Riset Kuantitatif: Teori dan Aplikasi pada Penelitian Bidang Manajemen dan 